\title{
Segmented and Band Form Neutrophils Measurement
}

National Cancer Institute

\section{Source}

National Cancer Institute. Segmented and Band Form Neutrophils Measurement. NCI

Thesaurus. Code C154755.

The determination of the amount of segmented and band form neutrophils present in a sample. 